\title{
Determinan Penerapan Anggaran Berbasis Kinerja pada Badan Layanan Umum Rumah Sakit Se-Pulau Sumbawa
}

\author{
Abdul Muis ${ }^{1}$ \\ Fakultas Ekonomi dan Bisnis \\ Universitas Mataram, Indonesia
}

\author{
Lalu M. Furkan ${ }^{2}$ \\ Fakultas Ekonomi dan Bisnis \\ Universitas Mataram, Indonesia
}

\section{Endar Pituringsih ${ }^{3}$ \\ Fakultas Ekonomi dan Bisnis Universitas Mataram, Indonesia}

Surel : muis4846@gmail.com

\section{ABSTRAK}

Penelitian ini bertujuan menguji pengaruh gaya kepemimpinan, kualitas sumber daya manusia, komitmen organisasi dan sistem pengendalian internal terhadap penerapan anggaran berbasis kinerja. Data diperoleh dengan penyebaran kuisioner kepada 68 responden. Analisis data menggunakan analisis regresi Linear berganda. Secara parsial variabel gaya kepemimpinan, komitmen organisasi dan sistem pengendalian internal masing-masing berpengaruh positif dan signifikan terhadap penerapan anggaran berbasis kinerja, sedangkan variabel kualitas SDM tidak berpengaruh terhadap penerapan anggaran berbasis kinerja pada BLU Rumah Sakit se-Pulau Sumbawa.

Kata Kunci: Anggaran Berbasis Kinerja; Gaya Kepemimpinan; Kualitas Sumber Daya Manusia; Komitmen Organisasi; Sistem Pengendalian Internal.

\section{Determinants Of The Implementation Performance-Based Budgets at Public Hospital Service Agencies In Sumbawa Island}

\begin{abstract}
This research aims to examine the effect of leadership style, quality of human resources, organizational commitment and internal control systems on the implementation of performance-based budgets. Data obtained by distributing questionnaires to 68 respondents. Data analysis using multiple linear regression analysis. Partially the variables of leadership style, organizational commitment and internal control systems each have a positive and significant effect on the implementation of performance-based budgets, while the quality of human resources has no effect on the implementation of performance-based budgets at BLU Hospitals throughout Sumbawa Island.
\end{abstract}

Keywords: $\quad$ Performance-Based Budget; Leadership Style; Quality Of Human Resources; Organizational Commitment; Internal Control System.

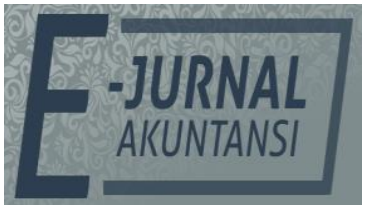

e-ISSN 2302-8556

Vol. 30 No. 10

Denpasar, Oktober 2020

Hal. 2657-2671

DOI:

10.24843/EJA.2020.v30.i10.p17

PENGUTIPAN:

Muis, A., Furkan, L. M. \& Pituringsih, E. (2020).

Determinan Penerapan

Anggaran Berbasis Kinerja Pada Badan Layanan Umum Rumah Sakit Se-Pulau Sumbawa. E-Jurnal Akuntansi, 30(10), 2657-2671

RIWAYAT ARTIKEL:

Artikel Masuk: 31 Agustus 2020 Artikel Diterima: 26 Oktober 2020

Artikel dapat diakses : https://ojs.unud.ac.id/index.php/Akuntansi/index 


\section{PENDAHULUAN}

Penyusunan anggaran pada organisasi sektor publik merupakan hal yang sangat rumit dan mengandung nuansa politik yang tinggi. Dalam organisasi sektor publik, penyusunan anggaran merupakan suatu proses politik. Anggaran merupakan managerial plan for action untuk memfasilitasi tercapainya tujuan organisasi. Menurut Connolly \& Hyndman (2009), untuk mencapai tata pemerintahan yang baik, maka organisasi sektor publik harus menerapkan asas transparansi. Salah satu wujud reformasi sistem penyusunan anggaran (budgeting reform) adalah penerapan Anggaran Berbasis Kinerja (Performance Based Budgeting). Permendagri No. 13 tahun 2006 menyatakan bahwa penganggaran yang baik akan memberikan dasar bagi pengukuran kinerja dan menghasilkan informasi kinerja yang valid dan akurat, sehingga dapat digunakan sebagai bahan penyusunan laporan kinerja untuk pengendalian. Dilihat dari sudut pandang rasional, implementasi anggaran berbasis kinerja merupakan isu teknis. Hal ini diungkapkan oleh Julnes, et al, (2001) yang menyatakan bahwa sistem pengukuran kinerja yang dilandasi oleh konsep value for money, dan anggaran yang berorientasi hasil yang menekankan pemikiran logis dan rasional dalam mengelola suatu perubahan dalam suatu organisasi.

Penerapan anggaran berbasis kinerja merupakan bagian yang tidak terpisahkan dalam proses penyempurnaan manajemen keuangan (anggaran negara), yang bertujuan untuk meningkatkan transparansi dan akuntabilitas pelayanan publik serta efektifitas dari pelaksanaan kebijakan dan program. Menurut Mubarak, (2007) untuk mengatasi kelemahan dalam penganggaran dan pengelolaan keuangan, diperlukan penyempurnaan pada landasan konstitusional mengenai pengelolaan anggaran negara, perbaikan sistem penyusunan anggaran, pengelolaan yang transparan dan akuntabilitas hingga peningkatan kualitas sumber daya manusia. Hal ini sejalan dengan Thynne, (2017) pelayanan publik tidak harus diselenggarakan oleh lembaga birokrasi murni, tetapi diselenggarakan oleh instansi yang dikelola ala bisnis (bussiness like) dengan menerapkan prinsip-prinsip kewirausahaan, dan manajemen sektor swasta. Transparansi dan akuntanbilitas anggaran pada instansi pemerintah seperti Badan Layanan Umum harus diwujudkan untuk meningkatkan pelayanan publik.

Badan Layanan Umum (BLU) merupakan instansi pemerintah yang diberikan mandat oleh Kementerian/Lembaga untuk menyelenggarakan layanan publik, seperti layanan kesehatan, pendidikan, pengelolaan kawasan dan pengelolaan dana. Pada dasarnya pengelolaan anggaran BLU telah diatur dalam Peraturan Pemerintah No. 23 tahun 2005. Dalam pasal 10 ayat 2, dinyatakan bahwa BLU menyusun Rencana Bisnis dan Anggaran (RBA) tahunan dengan mengacu kepada rencana strategis bisnis, dan pada ayat 3 dinyatakan bahwa RBA tersebut disusun berdasarkan basis kinerja dan perhitungan akuntansi biaya menurut jenis layanannya. Di dalam penjelasan PP No. 23 tahun 2005 juga dinyatakan bahwa BLU diharapkan menjadi contoh konkrit yang menonjol dari penerapan manajemen keuangan berbasis pada hasil (kinerja).

Dalam pelaksanaannya, upaya BLU dalam meningkatkan layanan kepada masyarakat saat ini masih belum maksimal. Hal ini sebagaimana 
Laporan Hasil Pemeriksaan (LHP) inspektorat Kabupaten Bima di Rumah Sakit Umum Daerah Kabupaten Bima tahun 2018 yang menyatakan bahwa terjadinya kasus pemulangan jenazah pasien dengan menggunakan sepeda motor atau ojek merupakan pelanggaran standar pelayanan prosedur sehingga itu merupakan murni kelalaian dari para petugas Rumah Sakit (Kabar harian bima.net, 28 Maret 2018). Selain itu, Syarifudin dalam kompas.com menyatakan terjadinya mogok kerja pegawai RSUD Kota Bima karena gaji selama 6 bulan belum terbayarkan adalah bentuk permasalahan tidak transparansinya Rumah Sakit Kota Bima dalam hal anggaran (Kompas.com, 11 Maret 2019, 18:28 WIB). Fenomena tersebut menggambarkan betapa buruknya pelayanan dan transparansi anggaran BLU Rumah Sakit di wilayah Bima Nusa Tenggara Barat.

Kesuksesan suatu organisasi atau setiap kelompok dalam suatu organisasi sangat tergantung pada kualitas kepemimpinan. Kepemimpinan dapat diartikan adalah suatu proses dimana seseorang dapat memimpin, membimbing, mengarahkan ataupun mempengaruhi pikiran dan tingkah laku orang lain untuk mencapai tujuan tertentu. Teori kepemimpinan menyatakan bahwa perilaku kepemimpinan yaitu menyebarkan informasi (informing); merencanakan (planning); mengorganisir (organizing); memecahkan masalah (problem solving); merumuskan peranan dan tujuan (clarifying); memonitoring (controlling); memotivasi (motivating); mencegah konflik dan mengembangkan kelompok (managing conflict and team building); serta membuat jaringan (networking), telah dijadikan sebagai acuan untuk mengetahui perilaku kepemimpinan yang sering dan jarang digunakan (Kaloh, 2009: 151). Berjalan atau tidaknya suatu organisasi ditentukan oleh faktor kepemimpinan. Fenomena yang terjadi di Rumah Sakit Kabupaten Bima merupakan sebuah kelalaian yang dilakukan oleh pegawai rumah sakit terhadap standar operasional prosedur (SOP) pelayanan terhadap pasien.

Kaihatu (2006) mengatakan bahwa gaya kepemimpinan seseorang adalah pola prilaku yang diperlihatkan seseorang pada waktu berupaya mempengaruhi aktifitas orang lain. Pimpinan rumah sakit se-Pulau Sumbawa tidak sukses, hal itu tercermin dari pola prilaku pimpinan yang belum mampu mengoreksi kinerja bawahan saat proses pelaksanaan kegiatan pelayanan di rumah sakit. Pemimpin yang sukses senantiasa mengantisipasi perubahan dengan sekuat tenaga, memanfaatkan semua kesempatan, memotivasi pengikut mereka untuk mencapai tingkat produktivitas yang tinggi, mengoreksi kinerja yang buruk dan mendorong organisasi ke arah sasaran-sasarannya (Bowo, 2008: 16).

Penelitian Wahyulina et al. (2015) mengkaji pengaruh gaya kepemimpinan dan sistem pengendalian intern terhadap penerapan anggaran berbasis kinerja. Hasil penelitian menunjukkan bahwa gaya kepemimpinan berpengaruh positif dan signifikan terhadap penerapan anggaran berbasis kinerja pada BLU Universitas Mataram. Hasil penelitian tersebut sejalan dengan penelitian yang dilakukan oleh Izzaty (2011), Rini (2013), Nawastri (2015) yang menyatakan gaya kepemimpinan berpengaruh terhadap penerapan anggaran berbasis kinerja. Namun, penelitian yang dilakukan Fitri (2013), dan Ayu, (2017) menunjukkan bahwa gaya kepemimpinan tidak berpengaruh terhadap penerapan anggaran berbasis kinerja, hal ini disebabkan karena tidak 
diterapkannya gaya kepemimpinan yang diarahkan kepada keterbukaan dan lebih bersifat humanis dimana tidak terpeliharanya hubungan serta komunikasi yang baik antara atasan dan bawahan.

Kurangnya pemahaman tentang kepemimpinan yang dimiliki oleh pimpinan Rumah Sakit merupakan penyebab tidak optimalnya penerapan anggaran berbasis kinerja, sehingga mengakibatkan terjadinya permasalahan. Hal tersebut berkaitan dengan tidak dilaksanakan SOP oleh bawahan atau petugas Rumah Sakit di Kabupaten Bima. Teori kepemimpinan bentuk situasional menjelaskan bahwa kepemimpinan situasional mempunyai dua yaitu unsur pengarahan (directive behavior) dan unsur bantuan (supporting behavior) (Stoner, 1996: 29) . Teori stewardship menjelaskan bentuk pola kepemimpinan dan hubungan para atasan dengan bawahannya dalam sebuah organisasi menggunakan mekanisme situasional. Teori ini memandang bahwa kepercayaan atas manajemen dapat terjadi jika manajemen bertindak sesuai dengan kepentingan, seperti kepentingan publik dan kepentingan shareholders. Hal ini sebagaimana Kurniawan (2013), menjelaskan bahwa kinerja perusahaan dapat meningkat karena adanya sifat amanah dan setia manajer perusahaan terhadap komitmen dalam perusahaan.

Hasil penelitian ini diharapkan dapat memberikan gambaran kepada BLU rumah sakit tentang faktor-faktor yang mempengaruhi penerapan anggaran berbasis kinerja, sehingga tidak salah dalam mengambil suatu kebijakan. Selain itu, hasil penelitian ini dapat dijadikan pedoman untuk membenahi sistem pengelolaan anggaran berbasis kinerja di dalam rumah sakit.

Berdasarkan tinjauan teoritis dan hasil beberapa penelitian terdahulu, peneliti mengidentifikasi 4 (empat) variabel independen yang mempengaruhi penerapan anggaran berbasis kinerja yaitu : Gaya Kepemimpinan, Kualitas Sumber Daya Manusia, Komitmen Organisasi dan Sistem Pengendalian Intern. Hubungan antara variabel dalam penelitian ini dapat dilihat pada gambar 1 berikut.

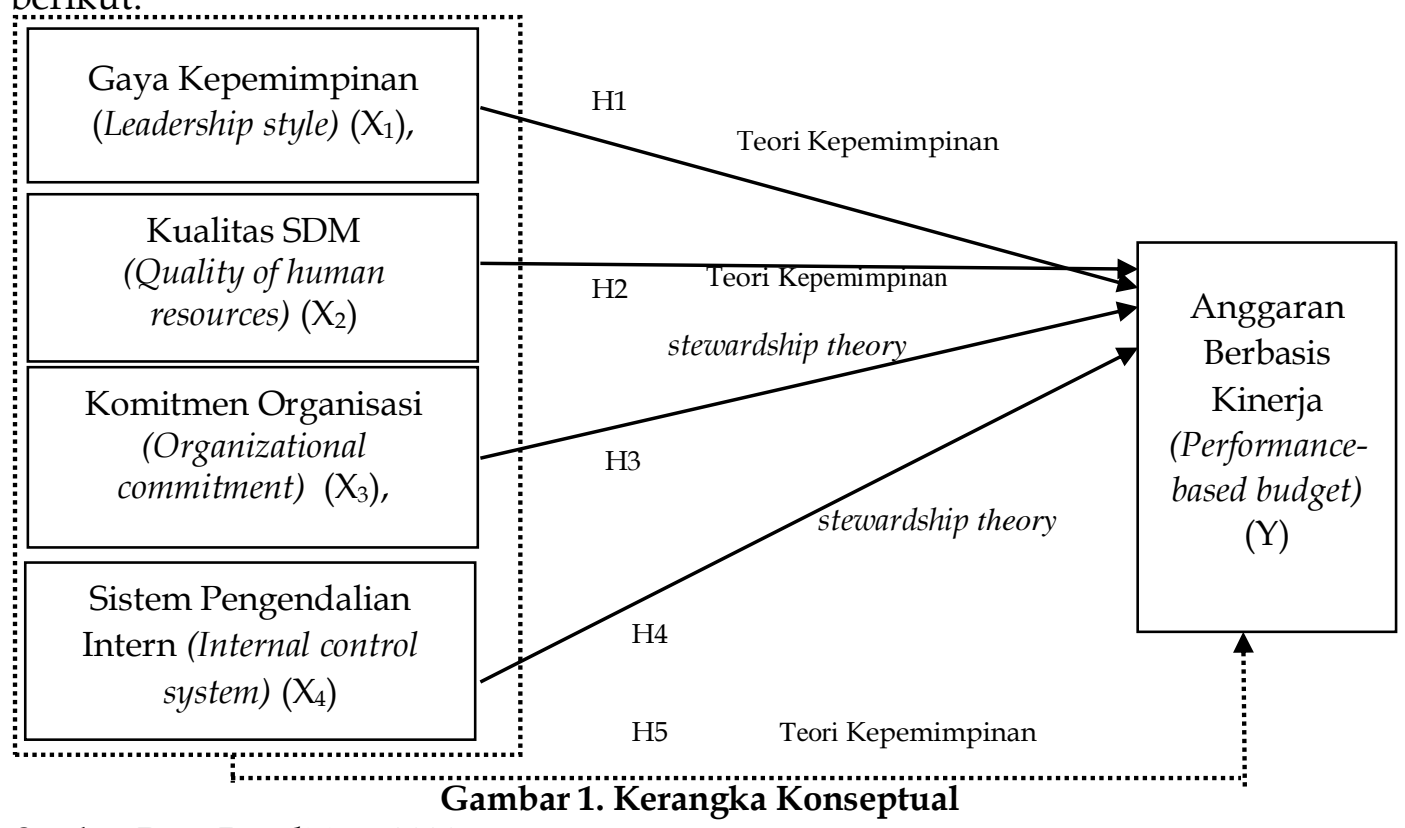

Sumber: Data Penelitian, 2020 
Perubahan orientasi penganggaran dari penganggaran tradisional menjadi penganggaran berbasis kinerja membutuhkan sistematika perubahan yang menyeluruh dari komponen organisasi terutama peran pemimpin dalam mengelola perubahan tersebut agar penerapan penganggaran berbasis kinerja dapat berjalan sesuai dengan peraturan yang berlaku dan pada akhirnya dapat berjalan efisien dan efektif dalam pengelolaan keuangan BLU. Hal tersebut dapat tercapai apabila seorang pemimpin memiliki kemampuan dalam mengarahkan dan membantu bawahan untuk mencapai target yang telah direncanakan. Menurut Nouri \& Parker (1998), kepemimpinan adalah kemampuan memengaruhi suatu kelompok ke arah pencapaian tujuan. Pemimpin yang sukses senantiasa mengantisipasi perubahan dengan sekuat tenaga memanfaatkan semua kesempatan, memotivasi pengikut mereka untuk mencapai tingkat produktivitas yang tinggi, mengoreksi kinerja yang buruk dan mendorong organisasi ke arah sasaran-sasarannya.

Penelitian tentang pengaruh gaya kepemimpinan terhadap penerapan anggaran berbasis kinerja pernah dilakukan oleh Fitri (2013) dan Ayu, (2017), yang menunjukkan bahwa gaya kepemimpinan tidak berpengaruh terhadap penerapan anggaran berbasis kinerja. Berdasarkan uraian, dapat dirumuskan hipotesis sebagai berikut.

$\mathrm{H}_{1}$ : Gaya Kepemimpinan berpengaruh positif terhadap Penerapan Anggaran Berbasis Kinerja.

Sumber daya manusia (SDM) berkualitas tinggi adalah SDM yang mampu menciptakan bukan saja nilai komparatif, tetapi juga nilai kompetitifgeneratif inovatif dengan menggunakan energi tertinggi seperti intelligence,creativity, dan imagination; tidak lagi semata-mata menggunakan energy kasar seperti bahan mentah, lahan, air, tenaga otot, dan sebagainya (Ndraha,1997:12). Seorang pemimpin harus mampu mengarahkan dan memotivasi bawahannya untuk meningkatkan kualitas diri mereka.

Fitri (2013) meneliti tentang pengaruh kualitas SDM terhadap Penerepan anggaran berbasis kinerja. Hasil penelitiannya membuktikan bahwa kualitas SDM berpengaruh positif terhadap penerapan anggaran berbasis kinerja. Disamping itu penelitian tersebut sejalan dengan penelitian yang dilakukan oleh Izzaty (2011), dan Ayu, (2017) yang menemukan adanya pengaruh positif dan signifikan antara kualitas SDM dengan penerapan anggaran berbasis kinerja. Berdasarkan uraian, dapat dibuat suatu hipotesis, sebagai berikut.

$\mathrm{H}_{2}$ : Kualitas sumber daya manusia berpengaruh positif terhadap Penerapan anggaran berbasis kinerja.

Menurut Griffin (2002: 15), komitmen organisasi adalah sikap yang mencerminkan sejauh mana seorang individu mengenal dan terikat pada organisasinya. Seorang individu yang memiliki komitmen tinggi kemungkinan akan melihat dirinya sebagai anggota sejati organisasi. Sebaliknya, seorang individu yang memiliki komitmen rendah lebih cenderung untuk melihat dirinya sebagai orang luar untuk mengekspresikan ketidakpuasan yang lebih besar menyangkut kondisi kerja, dan tidak ingin melihat dirinya sendiri menjadi anggota jangka panjang dari organisasi. Komitmen organisasi dapat timbuh manakala harapan kerja dapat terpenuhi oleh organisasi dengan baik. 
Ayu, (2017), mendefinisikan komitmen organisasi sebagai sikap yang mencerminkan sejauh mana seorang individu mengenal dan terikat pada organisasinya. Seorang individu yang memiliki komitmen tinggi kemungkinan akan melihat dirinya sebagai anggota sejati organisai dan berusaha menjadi yang terbaik sehingga kinerjanya pun akan meningkat. Untuk membentuk komitmen dibutuhkan peran seorang pemimpin yang dapat meyakinkan sehingga mampu menumbuhkan loyalitas bawahan terhadap suatu instansi atau organisas.

Menurut Darwis (2009), Teori stewardship menjelaskan bentuk pola kepemimpinan dan hubungan para atasan dengan bawahannya dalam sebuah organisasi menggunakan mekanisme situasional. Mekanisme ini meliputi filosofis manajemen dan perbedaan budaya organisasi, serta kepemimpinan dalam pencapaian tujuan bersama tanpa mengorbankan kepentingan masigmasing. Teori ini digunakan karena teori ini memandang bahwa kepercayaan atas manajemen dapat terjadi jika manajemen bertindak sesuai dengan kepentingan-kepentingan yang muncul, yaitu kepentingan publik pada umumnya dan kepentingan shareholders pada khususnya. Hal ini sebagaimana Kurniawan (2013) menjelaskan bahwa kinerja perusahaan dapat meningkat karena adanya sifat amanah dan setia manajer perusahaan terhadap komitmen dalam perusahaan.

Komitmen organisasi yang rendah akan menyebabkan individu tersebut hanya mementingkan dirinya sendiri atau kelompoknya sehingga pada akhirnya kinerja individu tersebut akan rendah pada organisasinya. Rendahnya kinerja individu terhadap organisasinya karena pengaruh rendahnya komitmen, secara tidak langsung akan mengakibatkan sulit dicapainya keberhasilan pada penerapan anggaran berbasis kinerja.

Penelitian tentang pengaruh komitmen organisasi terhadap penerapan anggaran berbasis kinerja pernah dilakukan oleh Pradana et al, (2014), Sembiring (2009), dan Rini (2013) yang menemukan bahwa komitmen organisasi berpengaruh positif dan signifikan terhadap penerapan anggaran berbasis kinerja. Semakin tinggi komitmen organisasi yang dimiliki oleh sutu organisasi maka penerapan anggaran berbasis kinerja semakin baik.

Berdasarkan uraian, maka dapat dibuatkan hipotesis pengaruh komitmen organisasi terhadap penerapan anggaran berbasis kinerja sebagai berikut.

$\mathrm{H}_{3}$ : Komitmen oganisasi berpengaruh terhadap penerapan anggaran berbasis kinerja.

Pengendalian intern merupakan suatu perencanaan yang meliputi struktur organisasi dan semua metode dan alat-alat yang dikoordinasikan yang digunakan dalam perusahaan dengan tujuan untuk menjaga keamanan harta milik perusahaan, memeriksa ketelitian dan kebenaran data akuntansi, mendorong efisiensi dan membantu mendorong dipatuhinya kebijakan manajemen yang telah ditetapkan. Peningkatan kompentensi dibidang penganggaran juga dapat dilaksanakan secara terkoordinasi dalam satu atap sehingga efisien dan efektif (Mauritz, 2008:36).

Penelitian tentang pengaruh Sistem Pengendalian Intern terhadap Penerapan Anggaran Berbasis Kinerja hanya baru sekali dilakukan yaitu oleh (Wahyulina et al. 2015). Sistem pengendalian intern yang baik dalam suatu 
organisasi akan mampu menciptakan keseluruhan proses kegiatan yang baik pula, sehingga nantinya akan memberikan suatu kenyataan bagi organisasi bahwa aktivitas yang dilaksanakan telah berjalan sesuai dengan tolak ukur yang telah ditetapkan secara efektif dan efisien, serta hal tersebut akan memberikan dampak positif bagi penerapan anggaran berbasis kinerja organisasi. Fungsi pengendalian intern memonitor apakah perilaku sudah berorientasi pada pencapaian kinerja yang baik, dan melakukan koreksi atas perilaku dan hasil yang menyimpang dari kinerja yang diinginkan sehingga semakin tinggi pengawasan intern maka kinerja manajerial akan meningkat pula. Menurut Raharjo (2007), Teori stewardship menjelaskan bentuk pola kepemimpinan dan hubungan para atasan dengan bawahannya dalam sebuah organisasi menggunakan mekanisme situasional. Berdasarkan uraian, dapat dibuatkan hipotesis sebagai berikut.

$\mathrm{H}_{4}$ : Sistem pengendalian intern berpengaruh positif terhadap penerapan anggaran berbasis kinerja.

Menurut Ayu, (2017), kemampuan manajerial seorang pemimpin tampak dalam merencanakan, menggerakkan, mengkoordinasikan, dan mengawasi serta mengendalikan kegiatan di lingkungan organisasi sangat dipengaruhi oleh perilaku pemimpin sebagai kegiatan nyata pemimpin dalam jabatan yang sedang diemban olehnya. Semua kemampuan manajerial tersebut tentunya harus didukung dengan gaya kepemipinan, kualitas SDM, Komitmen organisasi yang di miliki oleh para bawahan dalam suatu instansi. Gaya kepemimpinan yang situasional tentunya akan membuat para bawahan lebih nyaman dalam melakukan aktivitas dalam organisasi. Selain itu, komunikasi yang baik dan santun akan menciptakan suasan kerja yang baik sehingga dapat meningkatkan kulaitas SDM. Dengan kualitas SDM yang bagus maka seorang pemimpin lebih mudah dalam memberikan arahan kepada para bawahan sehingga komitmen organisasi akan terbentuk menjadi kuat.

Komunikasi yang efektif harus meluas di seluruh jajaran organisasi dimana seluruh pihak harus menerima pesan yang jelas dari manajemen puncak yang bertanggung jawab pada pengawasan. Semua pegawai harus paham peran mereka dalam sistem pengendalian intern seperti juga hubungan kerja antar individu. Mereka harus memiliki alat yang menyebarluaskan informasi penting. Fenomena pemulangan jenas menggunakan sepeda motor oleh keluarga pasien di Rumah Sakit Kabupaten Bima merupakan sebuah kasus lemahnya pengendalian intern di dalam instansi tersebut. Disamping itu, komunikasi yang kurang terbagun antara petugas kesehatan juga merupakan pemicu terjadinya masalah tersebut.

\section{METODE PENELITIAN}

Penelitian ini dilakukan pada tiga Rumah Sakit Umum Daerah yang terletak di Pulau Sumbawa. Menurut Sugiyono (2009:115) populasi adalah wilayah generalisasi yang terdiri atas: obyek/subyek yang mempunyai kualitas dan karakteristik tertentu yang ditetapkan oleh peneliti untuk dipelajari dan kemudian ditarik kesimpulannya". Berdasarkan penjelasan tersebut, yang menjadi populasi dalam penelitian ini adalah pegawai Rumah Sakit Umum Daerah se-Pulau Sumbawa, baik yang ada di Kota maupun Kabupaten Bima. 
Responden penelitian ini adalah pegawai RSUD yang terdiri dari kepala bagian, kepala sub bagian/seksi dan staf. Pegawai RSUD tersebut memahami mekanisme pengelolaan RSUD. Oleh karena itu, pegawai tersebut dijadikan responden dalam penelitian ini . Jumlah responden dalam penelitian ini adalah 68 responden.

Variabel independen $(\mathrm{X})$ yaitu variabel yang tidak dipengaruhi oleh variabel lainnya dalam model penelitian. Variabel independen dalam penelitian ini adalah Gaya Kepemimpinan (X1), Kualitas SDM (X2), Komitmen Organisasi (X3), Sistem Pengendalian Intern (X3). Variabel dependen yaitu variabel yang dipengaruhi oleh variabel lain dalam model penelitian. Variabel dependen dalam penelitian adalah Penerapan Anggaran Berbasis Kinerja $(Y)$.

$\mathrm{Y}=\mathrm{a}+\mathrm{b} 1 \mathrm{X} 1+\mathrm{b} 2 \mathrm{X} 2+\mathrm{b} 3 \mathrm{X} 3+\mathrm{b} 4 \mathrm{X} 4+\varepsilon$

Prosedur analasis data yang digunakan dalam penelitian ini yaitu dilakukan dengan cara melakukan perhitungan sehingga setiap rumusan masalah dapat ditemukan jawabannya secara kuantitatif. Dalam penelitian ini, analisis data dihitung dengan menggunakan software SPSS. Adapun persamaan model regresi secara sistematis sebagai berikut.

$\mathrm{ABK}=\alpha+\beta 1 \mathrm{GK}+\beta 2 \mathrm{KS}+\beta 3 \mathrm{KO}+\beta 4 \mathrm{SPI}+\varepsilon$

Keterangan:

$\mathrm{ABK}=$ Anggaran Berbasis Kinerja

$\mathrm{a} \quad=$ Konstanta

GK = Gaya Kepemimpinan

$\mathrm{KS} \quad=$ Kualitas SDM

$\mathrm{KO}=$ Komitmen Organisasi

SPI $=$ Sistem Pengendalian Intern

$\beta 1,2.3=$ Koefisien Regresi

$\varepsilon \quad=$ error

Teknik pengambilan sampel dalam penelitian ini adalah menggunakan metode sensus, yaitu semua pegawai yang terkait dengan penerapan anggaran berbasis kinerja, mulai dari penyusunan hingga pertanggungjawaban anggaran. Sehingga sampel dalam penelitian ini berjumlah 68 Responden. Alat pengumpulan data dalam penelitian ini adalah kuesioner (angket). Untuk menganalisis data yang sudah didapatkan menggunakan analisis Regresi Linier berganda. Sebelum melakukan analisis linier berganda, terlebih dahulu dilakukan uji validitas dan uji reliabilitas, setelah itu dilanjutkan dengan melakukan uji asumsi klasik terhadap data yang akan diolah.

\section{HASIL DAN PEMBAHASAN}

Hasil uji normalitas diperoleh nilai Asymp. Sig. (2-tailed) sebesar 0,200 atau lebih besar dari 0,05. Sehingga dapat disimpulkan bahwa data mempunyai distribusi normal. Hasil uji normalitas dapat dilihat pada Tabel 1, berikut.

Tabel 1. Uji Normalitas

\begin{tabular}{ll}
\hline & Unstandarized Residual \\
\hline $\mathrm{N}$ & 68 \\
Kolmogorov-Smirnov Z & 0,640 \\
Asymp. Sig. (2-tailed) & 0,200 \\
\hline
\end{tabular}

Sumber: Data Penelitian, 2020 
Uji multikolinearitas dilakukan dengan menggunakan nilai VIF (Variance Inflation Faktor). Nilai VIF mengindikasikan tingkat keeratan hubungan antara suatu variabel bebas dengan variabel bebas lainnya. Hasil uji multikolinearitas dapat dilihat pada Tabel 2, berikut.

Tabel 2. Pengujian Multikolinearitas

\begin{tabular}{|c|c|c|}
\hline \multirow{2}{*}{ Model } & \multicolumn{2}{|c|}{ Collinearity Statistics } \\
\hline & Tolerance & VIF \\
\hline Gaya Kepemimpinan (GK) & 0,618 & 1,618 \\
\hline Kualitas SDM (KS) & 0,711 & 1,406 \\
\hline Komitmen Organisasi (KO) & 0,659 & 1,517 \\
\hline Sistem Pengendalian Intern (SPI) & 0,726 & 1,378 \\
\hline
\end{tabular}

Sumber: Data Penelitian, 2020

Dari Tabel 2, dapat dilihat seluruh variabel independen memiliki nilai tolerance lebih dari 0,10 yang berarti tidak ada korelasi antar variabel independen. Hasil perhitungan nilai Variance Inflation Factor (VIF) juga menunjukkan hal yang sama, dimana seluruh variabel independen memiliki nilai VIF lebih kecil dari 10. Dengan demikian, dapat disimpulkan bahwa tidak ada masalah multikolonieritas antar variabel independen dalam model regresi penelitian ini.

Uji heteroskedastisitas dilakukan dengan menggunakan Uji Glejser yang digunakan untuk mendeteksi terjadi atau tidaknya heteroskedastisitas. Uji Glejser berwujud regresi nilai absolut residual terhadap variabel Independent. Hasil uji heterokedastisitas dapat dilihat pada Tabel 3, berikut.

Tabel 3. Pengujian Heterokedastisitas

\begin{tabular}{lc}
\hline Variabel Independen & Sig. \\
\hline Gaya Kepemimpinan (GK) & 0,188 \\
Kualitas SDM (KS) & 0,403 \\
Komitmen Organisasi (KO) & 0,224 \\
Sistem Pengendalian Intern (SPI) & 0,136 \\
\hline
\end{tabular}
Sumber: Data Penelitian, 2020

Dari Tabel 3, hasil uji Glesjser, nilai koefisien signifikansi semua variabel independen lebih besar dari 0,05, sehingga dapat disimpulkan tidak terjadi heteroskedastisitas dalam model regresi pada penelitian ini, serta layak untuk dilakukan pengujian hipotesis berikutnya.

Tabel 4. Hasil Regresi Linear Berganda

\begin{tabular}{|c|c|c|c|c|c|}
\hline \multirow[t]{2}{*}{ Model } & \multicolumn{2}{|c|}{$\begin{array}{l}\text { Unstandardized } \\
\text { Coefficients }\end{array}$} & \multirow{2}{*}{$\begin{array}{c}\begin{array}{c}\text { Std. } \\
\text { Coefficients }\end{array} \\
\text { Beta }\end{array}$} & \multirow[t]{2}{*}{$t$} & \multirow[t]{2}{*}{ Sig. } \\
\hline & $B$ & $\begin{array}{l}\text { Std. } \\
\text { Error }\end{array}$ & & & \\
\hline (Constant) & $-0,126$ & 4,553 & & $-0,028$ & 0,978 \\
\hline Pendidikan Staf Keuangan $\left(\mathrm{X}_{1)}\right.$ & 0,297 & 0,127 & 0,287 & 2,347 & 0,022 \\
\hline Pelatihan Akuntansi $\left(X_{2}\right)$ & 0,063 & 0,256 & 0,028 & 0,245 & 0,807 \\
\hline Penggunaan Aplikasi SAIBA ( $\left.\mathrm{X}_{3}\right)$ & 0,346 & 0,168 & 0,243 & 2,056 & 0,044 \\
\hline Komitmen Organisasi $\left(\mathrm{X}_{4}\right)$ & 0,260 & 0,114 & 0,258 & 2,291 & 0,025 \\
\hline Adjusted R Square & & & 0,51 & & \\
\hline Sig. F & & & 0,00 & & \\
\hline
\end{tabular}

Sumber: Data Penelitian, 2020

Berdasarkan perhitungan analisis regresi berganda pada Tabel 4, diketahui bahwa besarnya Adjusted $R$ Square adalah 0,511. Hal ini berarti 51,1\% variasi naik turunnya penerapan anggaran berbasis kinerja dijelaskan oleh 
variasi dari keempat variabel independen (gaya kepemimpinan, kualitas SDM, komitmen organisasi, dan sistem pengendalian intern). Sedangkan sisanya (100\% - 51,1\%) 48,9\% dijelaskan oleh variabel lain diluar variabel penelitian ini.Dari hasil analisis data, dapat disusun persamaan regresi sebagai berikut.

$$
\mathrm{ABK}=-0,126+0,297 \mathrm{GK}+0,063 \mathrm{KS}+0,346 \mathrm{KO}+0,260 \mathrm{SPI}+\mathrm{e}
$$

Uji simultan dengan uji $\mathrm{F}$ dilakukan untuk mengetahui pengaruh simultan variabel-variabel independen terhadap variabel dependen. Berdasarkan tabel perhitungan SPSS, ternyata F hitung lebih besar dari pada F tabel 11,33> 2,52: maka Ha diterima, Ho ditolak. Hal ini berarti terdapat pengaruh simultan variabel gaya kepemimpinan, kualitas SDM, komitmen organisasi, dan sistem pengendalian intern terhadap variabel independen penerapan anggaran berbasis kinerja.

Hasil tersebut mencerminkan bahwa gaya kepemimpinan, kualitas SDM, komitmen organisasi, dan sistem pengendalian intern ecara simultan berpengaruh positif dan signifikan terhadap Penerapan Anggaran Berbasis Kinerja pada BLU Rumah Saki se-Pulau Sumbaw. Hasil ini memberi makna bahwa semakin baik gaya kepemimpinan, kualitas SDM, komitmen organisasi, dan sistem pengendalian intern, maka semakin baik pula penerapan anggaran berbasis kinerja. Peran aktif para pimpinan dalam penyusunan anggaran yang didukung dengan komitmen organisasi dan kualitas SDM yang menjadi acuan dalam pengukuran kinerja, akan meningkatkan sistem pengendalian intern para pelaksana anggaran untuk mencapai tujuan dan sasaran yang telah ditetapkan, sehingga berdampak penerapan anggaran berbasis kinerja menjadi efektif.

Berdasarkan tabel perhitungan SPSS, ternyata $t$ hitung lebih besar dari pada $t$ tabel, maka Ha diterima dan Ho ditolak. Hal ini berarti hipotesis 1 yang menyatakan bahwa gaya kepemimpinan berpengaruh terhadap penerapan anggaran berbasis kinerja diterima. Hasil analisis tersebut menunjukkan bahwa gaya kepemimpinan mempunyai pengaruh yang positif dan signifikan terhadap penerapan anggaran berbasis kinerja. Koefisien korelasi parsial sebesar 0,297 menunjukkan setiap peningkatan gaya kepemimpinan pengelola BLU Rumah Sakit se-Pulau Sumbawa akan meningkatkan Penerapan Anggaran berbasis kinerja.

Peranan seorang pemimpin sangat penting untuk mencapai tujuan organisasi yang diinginka organisasi Badan Layanan Umum terutama berkaitan dengan peningkatan kinerja pegawai dalam melaksanakan standar efisiensi anggaran yang telah ditetapkan. Kinerja pegawai merupakan hasil kerja yang dapat dicapai seseorang atau sekelompok orang dalam suatu organisasi sesuai wewenang dan tanggung jawab masing-masing dalam rangka mewujudkan tujuan organisasi. Faktor kepemimpinan mempunyai peran yang sangat penting dalam meningkatkan kinerja pegawai karena kepemimpinan yang efektif memberikan pengarahan terhadap semua pekerja dalam mencapai tujuan organisasi.

Hasil pengujian hipotesis ini sejalan dengan penelitian yang dilakukan oleh Wahyulina et al. (2015), Izzaty (2011), Rini (2013), dan Nawastri (2015) yang menyatakan gaya kepemimpinan berpengaruh terhadap penerapan anggaran berbasis kinerja. Namun, hasil penelitian ini berbeda dengan hasil penelitian yang dilakukan Fitri (2013), dan Ayu, (2017) menunjukkan bahwa gaya 
kepemimpinan tidak berpengaruh terhadap penerapan anggaran berbasis kinerja.

Berdasarkan tabel perhitungan SPSS, variabel kualitas SDM memiliki nilai $t_{\text {hitung }}=0,245<t_{\text {tabel }}=1,999$ dan nilai tingkat signifikansi $i_{\text {hitung }}=0,807>5 \%$. Hal ini berarti hipotesis 2 yang menyatakan bahwa kualitas SDM berpengaruh terhadap penerapan anggaran berbasis kinerja ditolak.

Menurut Ayu, (2017), sumber daya manusia merupakan salah satu elemen organisasi yang sangat penting, oleh karena itu harus dipastikan bahwa pengelolaan sumber daya manusia dilakukan sebaik mungkin agar mampu memberikan kontribusi secara optimal dalam upaya pencapaian tujuan organisasi. Pengelolaan keuangan BLU yang baik termasuk pada tahap penganggaran, setiap satuan kerja harus memiliki sumber daya manusia yang berkualitas, yang didukung dengan latar belakang pendidikan yang memadai, sering mengikuti pendidikan dan pelatihan tentang anggaran berbasis kinerja, dan mempunyai keiinginan untuk mengembangkan pengetahuan dan kemampuannya. Tujuan tersebut tentunya akan akan tercapai apabila pegawai dan staf Rumah Sakit di pulau Sumbawa mengikuti arahan pimpinan rumah sakit. Hal ini sejalan dengan teori kepemimpinan yang dikemukakan oleh Stoner (1996: 29) yang mnyatakan bahwa pada dasarnya di dalam kepemimpinan situasional terdapat 2 unsur utama, yaitu unsur pengarahan (directive behavior).

Berdasarkan jawaban yang diberikan oleh responden diperoleh hasil bahwa variabel kualitas sumber daya manusia tidak mempengaruhi penerapan anggaran berbasis kinerja. Tidak berpengaruh disebabkan karena staff perencanaan atau pun pejabat yang ikut dalam menyusun anggaran berbasis kinerja masih banyak yang belum paham tentang anggaran berbasis kinerja. Hal ini disebabkan oleh kurangnya pendidikan dan pelatihan tentang anggaran berbasis kinerja. Minimnya staff pada bagian perencanaan juga merupakan salah satu penyebabnya. Menurut Rahayu et al (2007), sangat dibutuhkan bagian khusus yang mengelola perencanaan dan penganggaran karena proses perencanaan dan penganggaran berbasis kinerja membutuhkan waktu dan tenaga lebih dibandingkan sebelumnya. Oleh karena itu, pimpinan BLU Rumah Sakit hendaknya memberikan kesempatan untuk mengikuti pendidikan dan pelatihan tentang anggaran berbasis kinerja kepada staff dan pejabat yang ikut dalam penyusunan anggaran berbasis kinerja dan menambah staff dibagian perencanaan.

Hasil penelitian ini bertolak belakang dengan hasil penelitian Fitri (2013), Izzaty (2011) dan Ayu, (2017) yang masing-masing membuktikan bahwa kualitas SDM berpengaruh positif terhadap penerapan anggaran berbasis kinerja.

Berdasarkan tabel perhitungan SPSS, variabel komitmen organisasi memiliki nilai $t_{\text {hitung }}=2,056>t_{\text {tabel }}=1,999$ dan tingkat signifikansi $i_{\text {hitung }}=0,044<$ $5 \%$. Hal ini berarti hipotesis 3 yang menyatakan bahwa komitmen organisasi berpengaruh terhadap penerapan anggaran berbasis kinerja diterima.

Hasil analisis menunjukkan bahwa komitmen organisasi mempunyai pengaruh yang positif dan signifikan terhadap penerapan anggaran berbasis kinerja. Semakin tinggi komitmen yang dimiliki pegawai dan staf BLU Rumah sakit di Pulau Sumbawa, maka penerapan anggaran berbasis kinerja akan semakin efektif. Komitmen organisasi tersebut tentunya akan tercipta apabila 
terdapat pola hubungan yang harmonis atanra pejabat/pimpinan rumah sakit dengan para pegawai serta staf. Hasil pengujian ini sejalan dengan teori kepemimpinan yang dikemukakan oleh Darwis (2009) yang menjelaskan bentuk pola kepemimpinan dan hubungan para atasan dengan bawahannya dalam sebuah organisasi menggunakan mekanisme situasional.

Komitmen organisasi menunjukkan kepedulian dan loyalitas yang tinggi untuk tetap mengabdi dan menjadi bagian organisasi. Pegawai dan staf BLU Rumah sakit dengan komitmen organisasi yang tinggi akan selalu berusaha berbuat yang terbaik demi mencapai tujuan organisasi dan menempatkan kepentingan organisasi kepentingan pribadi. Komitmen yang tinggi akan mampu meningkatkan kinerja pegawai dan staf tersebut yang pada akhirnya pnerapan anggaran berbasis kinerja pada BLU Rumah sakit tersebut akan lebih mudah dan efektif.

Hasil penelitian ini sejalan dengan penelitian yang dilakukan oleh Pradana et al., (2014), Sembiring (2009), dan Rini (2013) yang masing-masing menemukan bahwa komitmen organisasi berpengaruh positif dan signifikan terhadap penerapan anggaran berbasis kinerja. Semakin tinggi komitmen organisasi yang dimiliki oleh sutu organisasi maka penerapan anggaran berbasis kinerja semakin baik.

Berdasarkan tabel perhitungan SPSS, variabel sistem pengendalian intern sebesar 0,260. Nilai signifikansi variabel sistem pengendalian intern 0,025 nilai ini signifikan pada tingkat signifikansi 0,05. Hasil ini didukung oleh hasil perhitungan nilai $t_{\text {hitung }} 2,2915>t_{\text {tabel }} 1,999$. Hasil analisis statistik dalam penelitian ini menunjukkan bahwa sistem pengendalian intern berpengaruh terhadap penerapan anggaran berbasis kinerja.

Berdasarkan hasil pengujian hipotesis, ditemukan bahwa sistem pengendalian intern berpengaruh positif signifikan terhadap penerapan Anggaran berbasis Kinerja. Hasil yang diperoleh sejalan dengan hipotesis penelitian yang diajukan. Dari hasil pengujian yang dihasilkan memperlihatkan bahwa semakin baik sistem pengendalian intern yang diterapkan oleh satuan kerja di lingkup BLU Rumah Sakit se-Pulau Sumbawa maka akan meningkatkan penerapan anggaran berbasis kinerja. Temuan ini sejalan dengan hasil penelitian dilakukan oleh (Wahyulina et al, 2015). Menurut Asmoko (2006), sistem pengendalian intern yang baik dalam suatu organisasi akan mampu menciptakan keseluruhan proses kegiatan yang baik pula, sehingga nantinya akan memberikan suatu kenyataan bagi organisasi bahwa aktivitas yang dilaksanakan telah berjalan sesuai dengan tolak ukur yang telah ditetapkan secara efektif dan efisien, serta hal tersebut akan memberikan dampak positif bagi penerapan anggaran berbasis kinerja organisasi.

\section{SIMPULAN}

Gaya kepemimpinan berpengaruh terhadap penerapan anggaran berbasis kinerja. Kualitas SDM tidak berpengaruh terhadap penerapan anggaran berbasis kinerja. Komitmen organisasi berpengaruh terhadap penerapan anggaran berbasis kinerja. Sistem pengendalian intern berpengaruh terhadap penerapan anggaran berbasis kinerja. 
Keterbatasan penelitian ini terletak pada kesulitan responden dalam memahami beberapa pertanyaan/pernyataan dalam kuisioner. Hal tersebut disebabkan karena latar belakang pendidikan responden yang lebih berkopetensi di bidang kesehatan bukan dibidang keuangan/anggaran, sehingga istilah-istilah yang berkaitan dengan mekanisme penyusunan anggaran berbasis kinerja sulit untuk mereka pahami.

Saran berdasarkan hasil penelitian ini yaitu pimpinan rumah sakit harus meperbanyak pelatihan-pelatihan yang berkaitan dengan anggaran supaya kualitas SDM dapat meningkat. Tidak berpengaruhnya kualitas SDM bukan disebabkan oleh rendahnya pendidikan pegawai rumah sakit, melainkan pegawai rumah sakit kurang memahami tentang mekanisme penyusunan anggaran berdasarkan kinerja. Oleh karena itu, pimpinan rumah sakit perlu mengadakan pelatihan-pelatihan tentang anggaran berbasis kinerja kepada para pegawai yang berkaitan dengan pengelolaan anggaran rumah sakit. Selain itu, saran Bagi peneliti selanjutnya adalah lebih menyederhanakan kalimat pertanyaan/pernyataan dalam kuisioner sehingga responden lebih mudah untuk memahami setiap item pertanyaan dalam kuisioner. Selain itu, peneliti selanjutnya juga dapat mengembangkan atau menambah item pertanyaan pada variabel kualitas SDM supaya kualitas SDM dapat digali lebih mendalam.

\section{REFERENSI}

Ayu, M. (2017). Pengaruh Gaya Kepemimpinan, Kualitas Sdm, Budaya Organisasi Dan Komitmen Organisasi Terhadap Penerapan Anggaran Berbasis Kinerja (Study Empiris Di Universitas Sang Bumi Ruwa Jurai Bandar Lampung). EKOMBIS SAINS: Jurnal Ekonomi, Keuangan Dan Bisnis, 2, 191-220. Https:/ / Doi.Org/10.24967/Ekombis.V2i2.291 Asmoko,

Hindri. (2006). Pengaruh Penganggaran Berbasis Kinerja terhadap Efektivitas Pengendalian. Jurnal Akuntansi Pemerintah 2 (2): 43-72

Bowo, Arief. (2008). Kepemimpinan. Jakarta: Pusat Pengembangan Bahan Ajar Universitas Mercu Buana.

Connolly, Ciaran dan Noel Hyndman, (2009). Accrual Accounting In The Public Sector : A Road Not Always Taken. http:// www.cipfa.org// media / files / regions / republicofreland / accrual_accounting.doc (14 Oktober 2019).

Darwis, Herman. (2009). Corporate Governance Terhadap Kinerja Perusahaan. Jurnal Keuangan dan Perbankan, 13 (3): 418-430.

Griffin, Ricky W. (2004). Manajemen, Edisi Ketujuh, Jilid 2. Jakarta: Erlangga.

Izzaty, Khairina Nur. (2011). Pengaruh Gaya Kepemimpinan dan Kualitas Sumber Daya Manusia Terhadap Penerapan Anggaran Berbasis Kinerja Badan Layanan Umum (Studi pada BLU Universitas Diponegoro Semarang). Skripsi. Universitas Diponegoro.

J. Kaloh, (2009), Kepemimpinan Kepala Daerah. (Pola Kegiatan, Kekuasaan, dan Perilaku Kepala Daerah dalam Pelaksanaan Otonomi Daerah), Jakarta: Sinar Grafika.

Julnes, P. de Lancer and Holzer, M. (2001). Promoting the Utilization of Performance Measures in Public Organization: an Emprirical Tudy of Factors Affecting Adoption and Implementation. Public Administration Review 61 (6): 693-708 
Kaihatu, T. S. (2006). Good Corporate Governance dan Penerapannya di Indonesia. Jurnal Manajemen dan Kewirausahaan, 8 (1): 1-9

Kurniawan, Muhammad. (2013). Pengaruh Komitmen Organisasi, Budaya Organisasi, Dan Kepuasan Kerja Terhadap Kinerja Organisasi Publik. Jurnal Fakultas Ekonomi Universitas Negeri: Padang.

Kabar harian bima. (2018). LHP Inspektorat, Kasus RSUD Bima Ditemukan Ada Kelalaian. khaba.net Edisi 28 Maret 2018.

Mauritz. (2008). Implementasi Perubahan Sistem Penganggaran yang Lebih Responsif untuk Peningkatan Kinerja Instansi Pemerintah. Jakarta: Rineka Cipta.

Mubarak, Ali. (2007). Implementasi Anggaran Berbasis Kinerja. Dalam Situs Suara Karya Online, 27 Juni.

Nouri, H. dan R. J. Parker. (1998). The Relationship Between Budget Participation And Job Performance: The Roles Of Budget Adequacy And Organizational Commitment. Accounting, Organization and Society. 23 (5): 467-483

Ndraha, Taliziduhu. (1997). Budaya Organisasi. Jakarta: Rineka Cipta.

Permendagri Nomor 13 tahun (2006), Tentang Pedoman Pengelolaan Keuangan Daerah sebagaimana telah diubah dengan Peraturan Menteri Dalam Negeri Nomor 59 tahun 2007.

Peraturan Pemerintah Nomor 23 Tahun (2005) tentang Pengelolaan Keuangan Badan Layanan Umum.

Pradana, Bagus Arya et al. (2014). Determinan Impelementasi Anggaran Berbasis Kinerja Badan Layanan Umum (Pada Universitas Negeri Semarang). Accounting Analysis Journal 3 (1): 136-152

Rini Tri Hastuti. (2013). Komitmen Organisasi Dan Gaya Kepemimpinan Dalam Penerapan Penganggaran Berbasis Kinerja Badan Layanan Umum. Jurnal Terpadu Ilmu Kesehatan, 3 (2): 175-179

Robbin, Stephen P. (2003). Perilaku Organisasi, Edisi Sembilan, Jilid 2. Jakarta : PT. Indeks Kelompok Gramedia.

Nawastri, Sabtari. (2015). Analisis faktor-faktor yang berpengaruh terhadap efektivitas penerapan anggaran berbasis kinerja (studi kasus pada skpd pemerintah kabupaten grobogan). Diponegoro Journal Of Accounting, 4 (2): 1-10

Sembiring, Benar Baik. (2009). Faktor-faktor yang Mempengaruhi Penyusunan Anggaran Pendapatan dan Belanja Daerah Berbasis Kinerja (Studi Empiris di Pemerintah Kabupaten Karo). Tesis. Universitas Sumatera Utara.

Stoner, James A. F. et al. (1996). Manajemen. Jakarta. PT Indeks Gramedia Group.

Sugiyono. (2012). Metode Penelitian Kuantitatif, Kualitatif dan REDD. Bandung: Alfa Beta.

Syarifudin. Pegawai RSUD Kota Bima Mogok Kerja karena Jasa Pelayanan Tidak Dibayar 3 Bulan. Kompas.com edisi 11/03/2019, 18:28 WIB

Thynne, I. (2003). Making sensi of organizations in public management: A back to-basics approach. Public organization review. 3 (1): 317-332

Raharjo, Eko. (2007). Teori Agensi Dalam Teori Stewardship Dalam Prespektif Akuntansi, Fokus Ekonomi, 2 (1): 37-46. 
Rahayu, Sri. Ludigdo, Unti dan Affandy, Didied. (2007). Studi Fenomologis terhadap Proses Penyusunan Anggaran Daerah bukti empiris dari satu Satuan Kerja Perangkat Daerah di Provinsi Jambi. SNA X. Unhas:Makassar.

Wahyulina, Hermanto, Biana Adha Inapty. (2015). Pengaruh Gaya Kepemimpinan Dan Sistem Pengendalian Intern Terhadap Anggaran Berbasis Kinerja Pada Blu Universitas Mataram. Jurnal JRAMB, Prodi Akuntansi, Fakultas Ekonomi, UMB Yogyakarta 1(2): 165-189 